\title{
収縮低減剤を使用したモルタルの収縮低減および 耐凍害性低下に影響する要因の検討 \\ INVESTIGATION OF AFFECTING FACTORS ON REDUCTANCE OF DRYING SHRINKAGE AND DEGRADATION OF FROST RESISTANCE OF MORTAR WITH SHRINKAGE REDUCING AGENT
}

\author{
鳴海 玲 子*, 張 文 艶**, 岸本嘉彦***, 濱 幸 雄**** \\ Reiko NARUMI, Wenyan ZHANG, Yoshihiko KISHIMOTO \\ and Yukio HAMA
}

\begin{abstract}
Shrinkage reducing agent (SRA) is one of chemical admixtures for concrete during mixing, which was developed to reduce drying shrinkage in concrete due to low surface tension. The frost resistance of mortar incorporating the traditional type SRA could be reduced. Therefore, the modified type SRA was developed to improve the frost resistance. In this study, shrinkage properties, frost resistance, pore structure and characteristics of pore solution in the mortar using the traditional and modified types SRA were discussed. It was suggested that the characteristics of pore solution in addition to the pore structure affected the shrinkage properties and frost resistance.
\end{abstract}

Keywords : Shrinkage reducing agent, Drying shrinkage, Frost resistance, Pore structure, Surface tension, Viscosity 収縮低減剤, 乾燥収縮, 而凍害性, 空隙構造, 表面張力, 粘性

\section{1. はじめに}

コンクリートの乾燥収縮に起因するひび割れは構造物の耐久性に 大きな影響を及ぼす。乾燥収縮の低減策の一つとして, 収縮低減剤の 利用がある。収縮低減剂は, 収縮機構のひとつである毛細管張力説に 基づき, 細孔溶液の表面張力の低下による乾燥収縮の抑制を期待して 1980 年代に開発されたものである。しかし, 従来のアルコール系の 収縮低減剤を使用したコンクリートでは耐凍害性が低下寸ることが 指摘されており, 寒冷地における収縮低減剤の使用には未だ問題があ る。そこで近年では, 細孔溶液の凍結に伴う未凍結水の水晶への移動 を抑制することにより耐凍害性の向上を図った鉱物油系の耐凍害性 改良型収縮低減剤が開発され ${ }^{1)}$ ，実用化されている。

収縮低減剂を使用したコンクリートの収縮性状および而凍害性に ついては多くの研究が行われている。例えば，福島ら ${ }^{2)} は$ 収縮低減剤 を使用した場合の収縮性状と細孔構造の関係について, C-S-H の一次 粒子を構成する各層の方向が揃うことにより直径 $4.4 \mathrm{~nm}$ 以下の細孔 は減少し, 平均直径 4.4-5.3nm の収縮低減剤の分子が直径 $4.4 \mathrm{~nm}$ 以上 の細孔に存在することでシリケートアニオン鎖の脱水による重合を 抑制して直径 $4.4 \mathrm{~nm}$ 以上の細孔量が増加することを報告している。ま た，丸山ら ${ }^{3)^{4}}$ はセメント硬化体の体積変化を材料内水分の分離圧に
より表わ寸数式を提示し, 同一含水率の場合には比表面積の増加に 伴い収縮量が増加すること, および同一吸着厚さの場合には比表面 積が増加するほど含水率も増加して収縮駆動力が増大寸ることを 明らかにした。さらに, 収縮低減剤を使用した場合には, セメント 硬化体の水和生成物表面に存在する収縮低減剤の疎水基が水分子 の吸着を阻害することにより水分が吸着可能な比表面積を減少さ せ, 結果として, 収縮駆動力に影響する分離圧の減少が収縮を抑制 すると報告している。高田ら ${ }^{5}$ はアルコール系の収縮低減剤を用い た場合には気泡間隔係数が小さくても而凍害性が低下寸ることを 指摘し，西ら のは空気泡内で形成した水晶周囲には高濃度の収縮低 減剂が存在し, 毛細管空隙内の未凍結水との濃度勾配に起因する未 凍結水の移動が凍結水量を増加させ, 耐凍害性が低下寸る可能性が あると報告している。著者ら ${ }^{7)}$ も収縮低減剂を使用したモルタル の耐凍害性低下について, 空隙構造の観点から検討を行ったが, 十 分に機構を解明するに至っていない。また, 収縮低減剤の表面張力 が純水よりも低いことから, 表面張力を変数として含む凍結点降下 の理論式 ${ }^{8)}$ 用いてモルタルに内在する水分の凍結温度が上昇する 可能性を示しているが，実験的な検証は行っていない。

一方, セメント硬化体内の細孔溶液は, 乾燥挙動および凍結融解
室蘭工業大学大学院工学研究科建築社会基盤系専攻 博士前期課程

** 室蘭工業大学大学院 研究員 $\cdot$ 博士 $($ 工学 $)$

*** 室蘭工業大学大学院工学研究科くらし環境系領域 助教・博士 (工学)

**** 室蘭工業大学大学院工学研究科 $<ら し$ 環境系領域 教授・博士 (工学)
Graduate Student, Graduate School of Engineering, Muroran Institute of Technology

Postdoctoral Fellow, Graduate School of Engineering, Muroran Institute of Technology, Dr. Eng.

Assistant Prof., College of Environmental Technology, Muroran Institute of Technology, Dr. Eng.

Prof., College of Environmental Technology, Muroran Institute of Technology, Dr. Eng. 
挙動と密接に関係し, 細孔溶液の表面張力や粘性は硬化体性状に影響 を及ぼす重要な要因である。佐久田ら ${ }^{9}$ は, 収縮低減剤を使用したセ メントペーストと収縮低減剂未使用のセメントペーストから搾り出 した細孔溶液の表面張力を測定し，いずれの場合においてもその細孔 溶液の表面張力が純水よりも低いことを指摘している。また張ら ${ }^{10}$ は，収縮低減剤以外の一般的な混和剤を含めた検討を行い，いずれの 混和剤の場合でも混和剤溶液の表面張力は純水よりも低いが, 混練直 後のセメントペーストから遠心分離により採取した細孔溶液では, 収 縮低減剂以外の一般的な混和剤の場合には純水の表面張力と同程度 に戻るのに対して, 収縮低減剤の表面張力は低い值を保持していたこ とを報告している。さらに, 収縮低減剤および $\mathrm{AE}$ 剂を含んだ混和剂 溶液の粘度には大きな差が認められないとする指摘もある ${ }^{11)}$ 。しか し, 上記既往文献の細孔溶液の表面張力の測定結果に差があることや, 液体の粘度の温度依存性が考慮されていないことから, 細孔溶液の性 状が硬化体の細孔構造や収縮性状, 而凍害性に及ぼす影響が明らかに なっているとはいえない。

そこで, 本研究ではアルコール系の従来型収縮低減剤と鉱物油系の 改良型收縮低減剂を対象として,これらを混和したモルタルの収縮性 状および而凍害性に影響を及ぼす要因について検討することを目的 とする。具体的には，全空隙量，細孔径分布，比表面積，気泡組織の 測定を行い,これらの空隙構造がモルタルの収縮性状および而凍害性 に及ぼす影響について検討した。さらに，収縮低減剤を混和した混和 剂溶液およびセメントペーストから採取した細孔溶液の表面張力, 凍 結温度 (融点)，粘度を測定し，これらの性状がモルタルの耐凍害性 に及ぼす影響について検討した。

\section{2. 実験計画および方法}

\section{2-1 空隙構造の影響に関する実験}

2-1-1 実験計画

表 1 に収縮低減剂を用いたモルタルの収縮性状および而凍害性に 及ぼす空隙構造の影響に関する実験計画を示す。モルタルには，普通 ポルトランドセメント (密度 : $3.16 \mathrm{~g} / \mathrm{cm}^{3}$ ), 白老産陸砂（表乾密度： $2.67 \mathrm{~g} / \mathrm{cm}^{3}$ ，吸水率：1.57\%，実績率：66.5\%）を使用した。また，収 縮低減剂を使用しないベースモルタルの目標空気量を $5.0 \%$ と定め, アルキルエーテル系 $\mathrm{AE}$ 剮およびポリアルキレングリコール誘導体 系消泡剤を使用して空気量を調整した。それに加え，アルコール系の グリコールエーテル系誘導体を主成分とする従来型収縮低減剤 $(\mathrm{H})$, 炭化水素化合物およびグリコールエーテル系誘導体により構成され る鉱物油系の耐凍害性改良型収縮低減剤(S)を用いた。

作製したモルタルは水セメント比 0.5 , セメント砂比 $1: 3$ とし, 収

表 1 収縮低減剂を用いたモルタルの収縮性状および 耐凍害性に及ぼす空隙構造の影響に関する実験計画

\begin{tabular}{|c|c|c|c|c|c|c|c|}
\hline \multirow{2}{*}{ 記号 } & \multirow{2}{*}{$\mathrm{W} / \mathrm{C}$} & \multirow{2}{*}{ C:S } & \multicolumn{2}{|c|}{ 収縮低減剂 $(C \times w t . \%)$} & \multirow{2}{*}{$\begin{array}{c}A E x_{n} \\
(C \times \text { wt.\%) }\end{array}$} & \multirow{2}{*}{\begin{tabular}{|c|} 
消泡剂 \\
$(\mathrm{C} \times$ wt.\%) \\
\end{tabular}} & \multirow{2}{*}{ 試験項目 } \\
\hline & & & $\mathrm{S}$ & $\mathrm{H}$ & & & \\
\hline ベース & \multirow{7}{*}{0.5} & \multirow{7}{*}{$1: 3$} & & & \multirow{7}{*}{0.005} & \multirow{7}{*}{0.04} & \multirow{7}{*}{$\begin{array}{c}\text { 乾燥収縮試験 } \\
\text { 凍結融解試験 } \\
\text { リニアトラドバース法 } \\
\text { 水銀圧入法 } \\
\text { アルキメデス法 } \\
\text { 水蒸気吸着法 }\end{array}$} \\
\hline S0.4 & & & 0.4 & - & & & \\
\hline S1.4 & & & 1.4 & - & & & \\
\hline S2.3 & & & 2.3 & - & & & \\
\hline $\mathrm{H} 0.4$ & & & - & 0.4 & & & \\
\hline $\mathrm{H} 1.4$ & & & - & 1.4 & & & \\
\hline $\mathrm{H} 2.3$ & & & - & 2.3 & & & \\
\hline
\end{tabular}

縮低減剂はメーカーの推奨範囲に基づき最小值, 標準值, 最大值 $(2$, $\left.7,12 \mathrm{~kg} / \mathrm{m}^{3}\right)$ をモルタル調合の外割で後添加した。また，練上がり 性状として,フロー值と空気量を測定した。試験体は 40×40×160mm の角柱試験体および $\phi 50 \times 100 \mathrm{~mm}$ の円柱試験体として打設後 1 日で 脱型し, 乾燥収縮試験を行う試験体は材齢 7 日まで, 凍結融解試験, 細孔構造, 比表面積, 気泡組織の測定を行う試験体はそれぞれ材齢 28 日まで $20^{\circ} \mathrm{C}$ 水中養生を行った。

\section{2-1-2 試験方法}

\section{（1）乾燥収縮試験}

試験体には 40×40×160mm の角柱試験体を用い，JIS A 1129 に準 じて $20^{\circ} \mathrm{C} 60 \% \mathrm{RH}$ の恒温恒湿室においてダイヤルゲージ法により長 さ変化率，試験体質量を所定の材齢ごとに測定した。

\section{（2）凍結融解試験}

乾燥収縮試験と同様に，40×40×160mm の角柱試験体を用い，JIS $\mathrm{A} 1148 \mathrm{~A}$ 法に準じ, 最低温度を $-18^{\circ} \mathrm{C}$, 最高温度を $5^{\circ} \mathrm{C}$ に設定した凍 結融解を 1 日あたり 6 サイクルの条件で与えた。測定項目は質量お よび一次共鳴振動数として, サイクル数の経過による一次共鳴振動 数の変化から相対動弾性係数および而久性指数を算出した。モルタ ル試験での耐久性指数はコンクリート試験と同一ではないが, 耐凍 害性に対する一つの指標として, 取り扱うことが可能であると想定 した。

\section{（3）全空隙量の測定}

全空隙量はアルキメデス法により測定した ${ }^{12)}$ 。試料は，モルタル 試験体を $5 \mathrm{~mm}$ 角の立方体に切断後, アセトン置換による水和停止 および D-Dryによる乾燥をそれぞれ 1 日間行い, 約 20 個のサンプ ルを用いて測定を行った。

\section{（4）細孔径分布の測定}

細孔径分布の測定は全空隙量測定と同様の処理を行った試料を 用いて, 水銀圧入ポロシメーター（米国産 Quantachrome 社製 PoreMaster33）により行った。最大圧力を 220MPa，すなわち最小 直径 $6 \mathrm{~nm}$ までの細孔径分布を測定した。なお, 本実験では新ら ${ }^{13)}$ と同様の方法で, $0.1 \mathrm{MPa}$ から $200 \mathrm{MPa}$ まで加圧して水銀を圧入し た後, $0.1 \mathrm{MPa}$ まで減圧して水銀を排出する工程を 2 回連続で行い, 細孔の形状および連続性の影響により空隙内に残された水銀量を インクボトル細孔量として, 1 回目の侵入曲線と 2 回目の侵入曲線 の差から算出した。

\section{（5）比表面積の測定}

水蒸気等温吸脱着線測定装置（米国製 Quantachrome 社製 Hydrosorb 1000）を用いて定容法により水蒸気吸着等温線と脱着等 温線の両方を測定した。比表面積測定用の試料は全空隙量測定と同 様の処理を行った $5 \mathrm{~mm}$ 角の試料とした。

岸本ら ${ }^{14)}$ は, モルタルサンプルを用いた場合にマクロ孔も考慮す るためには試料のサイズを $5 \mathrm{~mm}$ 以上にする必要があり, 再現性を 有する測定結果を得られる相対圧の上限值は 95\%であることを報 告している。丸山ら ${ }^{15)}$ はセメント硬化体の乾燥程度により C-S-H が変質して水蒸気 BET 比表面積が変化するとしている。そこで, これらを参考に試料の乾燥条件および測定条件を以下のように決 定した。試料は D-dry 終了後に密閉可能な容器に入れ, 実験室内に 静置したデシケーター内に保存した。保存中に生じる水分吸着を排 除するため, 測定セルに試料を移した後, 測定直前まで 3 日間の真 
空乾燥を再度行い，セル内に窒素を充填後直ちに測定を開始した。測 定条件は, 温度を $20^{\circ} \mathrm{C}$, 許容圧力較差を $0.05 \mathrm{mmHg}$, 平衡時間を 300 秒とし，測定点は，吸脱着線ともに相対圧 5 から $95 \%$ までの $5 \%$ 刻み に設定した。測定された水蒸気吸着線から, Adolphs と Setzerにより 提案された ESW 理論 ${ }^{16) 17718) 19}$ に基づいた ESW 比表面積を算出した。 一般に，比表面積には BET 比表面積 ${ }^{200}$ が用いられるが，これは単分 子吸着が可能となる比表面積を算出しており, 相対圧 $0.35 \sim 0.50$ の範 囲における比表面積を意味する。一方，ESW 理論に基づく比表面積 は全相対圧で適用可能である。すなわち，単分子吸着による比表面積 だけではなく, 単分子吸着終了後の表面構造の変化および毛細管凝縮 の影響による比表面積についても算出可能であるという利点をもつ ている。ここでは，単分子吸着が行われた範囲で水分子が吸着可能な 比表面積を $\mathrm{ESW}$ 理論に基づいて求めた。

\section{（6）気泡組織の測定}

測定項目はリニアトラバース法 (ASTM C-457-98 $8^{21)}$ )による気泡間 隔係数とした。リニアトラバース法用の試料は角柱試験体から切り出 した 40×40×25mm の板状のものを使用した。測定には倍率 175 倍の マイクロスコープを用い, 気泡間隔係数はトラバース線上(全長 : 約 $1400 \mathrm{~mm})$ を通過する気泡の弦長の測定值に基づき算出した。

\section{2-2 混和剤溶液・細孔溶液の各種性状の影響に関する実験 2-2-1 実験計画}

表 2 に混和剤溶液・細孔溶液の各種性状の影響に関する実験計画を 示す。 $2-1-1$ 項に示した実験計画と同じ収縮低減剂 $\mathrm{S}, \mathrm{H}$ および 一般的な混和剤であるリグニンスルホン酸塩およびオキシカルボン 酸塩を主成分とする $\mathrm{AE}$ 減水剤を使用した。

混和剤溶液実験として，2-1-1 項に示した水セメント比 0.5 , セメント砂比 1:3 のモルタル試験体を想定して, 収縮低減剤の使用量 の最小值, 標準值, 最大値に相当する濃度にそれぞれ調整した収縮低 減剤溶液, 標準使用量の濃度に調整した $\mathrm{AE}$ 減水剂溶液, およびこれ らの原液と精製水を加えた各溶液の表面張力および粘度を測定した。 また, 粘度の測定においては収縮低減剂濃度の影響をより詳細に把握 するために $0 ， 1 ， 2 ， 3 ， 4 ， 5 \% の 6$ 条件の濃度の溶液を追加した。

さらに, 検討するモルタル試験体のセメント硬化体部分に存在する 細孔溶液について検討するために, 水セメント比 0.5 のセメントペー

表 2 混和剂溶液・細孔溶液の各種性状の 影響に関する実験計画

\begin{tabular}{|c|c|c|c|c|c|c|}
\hline \multirow{2}{*}{$\begin{array}{c}\text { 混和剂 } \\
\text { 種類 }\end{array}$} & \multirow[t]{2}{*}{ 濃度(\%) } & \multicolumn{2}{|c|}{ 表面張力 (白金プレート法) } & \multirow{2}{*}{$\begin{array}{c}\text { 融点 } \\
(\text { 低温DSC) }\end{array}$} & \multirow{2}{*}{$\begin{array}{c}\text { 粘度 } \\
\text { (毛細管 } \\
\text { 粘度計) } \\
\text { 混和剤溶液 } \\
\end{array}$} & \multirow{2}{*}{$\begin{array}{c}\text { 凍結水率 } \\
\text { (交流 } \\
\text { 二電極法) } \\
\text { モルタル }\end{array}$} \\
\hline & & 混和剂溶液 & 細孔溶液 & & & \\
\hline & 水 & 0 & $\mathrm{O}$ & $\mathrm{O}$ & $\mathrm{O}$ & $\mathrm{O}$ \\
\hline \multirow{9}{*}{ S } & 0.79 & $\mathrm{O}$ & $\mathrm{O}$ & - & - & - \\
\hline & 1.00 & - & - & - & 0 & - \\
\hline & 2.00 & - & - & - & $\mathrm{O}$ & - \\
\hline & 2.73 & - & - & - & 0 & 0 \\
\hline & 3.00 & - & - & - & 0 & - \\
\hline & 4.00 & - & - & - & $\mathrm{O}$ & - \\
\hline & 4.40 & $\mathrm{O}$ & $\mathrm{O}$ & $\mathrm{O}$ & - & - \\
\hline & 5.00 & - & - & - & 0 & - \\
\hline & 100.00 & $\mathrm{O}$ & - & - & - & - \\
\hline \multirow{3}{*}{$\mathrm{H}$} & 0.79 & $\mathrm{O}$ & $\mathrm{O}$ & - & - & - \\
\hline & 4.40 & $\mathrm{O}$ & $\mathrm{O}$ & - & - & - \\
\hline & 100.00 & $\mathrm{O}$ & - & - & - & - \\
\hline \multirow{2}{*}{$\mathrm{AE}$} & 2.00 & $\mathrm{O}$ & $\mathrm{O}$ & - & - & - \\
\hline & 100.00 & 0 & - & - & - & - \\
\hline
\end{tabular}

ストを作製し, 対象とするモルタルの細孔溶液と搾り出した細孔溶 液を同等であると仮定した。使用した混和剂および使用量は混和剂 溶液実験と同量である。試験体は $\phi 50 \times 100 \mathrm{~mm}$ の円柱試験体とし， 養生条件は 3 日間 $20^{\circ} \mathrm{C}$ 水中養生を行った後, 佐久田ら ${ }^{9)}$ と同様の方 法として 3 軸方向から拘束状態の試験体に荷重をかけ, 搾り出し法 により細孔溶液の採取を行い, 表面張力, 凍結温度（融点）の測定 に供した。

また，交流二電極法による凍結水率を測定するため，水セメント 比 0.5 , セメント砂比 1:3 の収縮低減剂を使用しないモルタルと収 縮低減剤 S をセメント重量に対して $1.4 \%$ 使用したモルタルを作製 し，それぞれ材齢 28 日まで封縅養生を行った。

\section{2-2-2 試験方法}

\section{（1）溶液の表面張力の測定}

表面張力の測定は， $20 \pm 2^{\circ} \mathrm{C} ， 60 \pm 3 \% \mathrm{RH}$ の範囲内に制御された恒 温恒湿室において同程度の温度の溶液を用いて白金プレート法 ${ }^{22)}$ により行った。

\section{（2）溶液の凍結温度（融点）の測定}

細孔溶液の凍結温度（融点）の測定は，モルタルの細孔を想定し て直径 $10 \mathrm{~nm}$ の均一孔を有する多孔質シリカ(FUJI SILYSIA CHEMICAL 製 CARiACT Q-10)に採取した細孔溶液を含浸させたも のを試料とし, 低温 DSC により行った。測定条件は, Ishikiriyama $ら^{2324)}$ の測定と同様に温度範囲を-30 から $10^{\circ} \mathrm{C}$, 温度勾配を $0.31^{\circ} \mathrm{C}$ /min に設定した。また, 凍結時に生じる過冷却の影響を排除するた めに, 融解過程において吸熱量を測定し, 融点開始側にある変曲点 の接線とベースラインの交点として示される融点を算出した。

\section{（3） モルタルの凍結水率の測定}

モルタル試験体中の凍結水率の測定は交流二電極法 ${ }^{25}$ により行 った。これはセメント硬化体に内在する溶液の電気的性質を利用し, 凍結前後における水の比抵抗の変化から凍結水率を算出する方法 である。溶液の電気伝導率は式(1)のように絶対温度の関数として示 される。

$$
K_{\text {sol }}=\frac{1}{\rho}=a_{1} \exp \left(\frac{b_{1}}{T}\right)
$$

ここで, $K_{s o l}$ は温度 $T$ における溶液の電気伝導率（ただし, 凍結に よる相変化のない場合) $(\mathrm{S} / \mathrm{m}), \rho$ は比抵抗 $(\Omega \cdot \mathrm{m}), T$ は絶対温度 $(\mathrm{K})$, $a_{l}, b_{1}$ は定数である。

溶液は複数の電解質が存在しており, 溶液全体の電気伝導率 $K$ は各電解質の電気伝導率 $K_{n}$ の総和として式(2)に示され, 凍結水率 は式(3)で示される。

$$
\begin{aligned}
& K=\sum K_{n}=W_{n} K_{\text {sol }}+\left(1-W_{n}\right) K_{\text {ice }} \\
& W_{f}=1-W_{n}=\frac{K_{\text {sol }}-K}{K_{\text {sol }}-K_{\text {ice }}}
\end{aligned}
$$

ここで, $K$ は温度 $T$ における電気伝導率の実測値 $(\mathrm{S} / \mathrm{m}), \quad K_{i c e}$ は温 度 $T$ における水の電気伝導率 $(\mathrm{S} / \mathrm{m}), W_{n}$ は未凍結水率, $W_{f}$ は凍結水 率である。

封緘状態の $\phi 50 \times 100 \mathrm{~mm}$ の試験体内部に埋設した熱電対および 電極により試験体内の温度と電極間の比抵抗を 30 分ごとに測定し, 比抵抗の変化から凍結水率を算出した。また, 測定はプログラム恒 温槽内において行い, 温度範囲は- 18 から $10^{\circ} \mathrm{C}$, 昇温・降温速度は 
共に試験体内部に大きな温度勾配が生じないように $1.7^{\circ} \mathrm{C} / \mathrm{h}$ に設定し た。凍結融解サイクルは共に 1 サイクルとした。電気抵抗の測定には $1 \mathrm{kHz}$ の交流電流を用い, 印可電圧は $1 \mathrm{~V}$ とした。

\section{（4）溶液の粘度の測定}

混和剤溶液の粘性の測定には, 毛細管粘度計ウベローデ（柴田科学 株式会社製 : 粘度計定数 $0.0035 \mathrm{~mm}^{2} / \mathrm{s}^{2}$ ) を用いた。JIS Z8803 に準じ, 一定量の混和剂溶液が毛細管粘度計の 2 本の標線を重力によりそれ ぞれ通過する時間を測定することで動粘度を求め, 別途測定した混和 剂溶液の密度を用いて, 動粘度から粘度に換算した。温度による影響 を検討するために設定温度は $25 ， 20 ， 15 ， 10 ， 5 ， 3 ， 0.5^{\circ} \mathrm{C} の 7$ 条件 とした。さらに, 収縮低減剤の濃度による影響を検討するために 5 種類の濃度の練混ぜ溶液を用いて $15^{\circ} \mathrm{C}$ の恒温槽内で粘度の測定を行 った。

\section{3. 実験結果および考察}

\section{3ー1 収縮低減剂を使用したモルタルの空隙構造が収縮性状およ び耐凍害性に及ぼす影響}

\section{3-1-1 収縮低減剤を使用したモルタルの基礎性状}

\section{（1）乾燥収縮試験結果}

図 1 にセメント重量に対する収縮低減剤使用量と長さ変化率の関 係を示す。S0.4 のみベースモルタルとほぼ同じ収縮量ではあるが，基 本的には収縮低減剤の使用により収縮が低減されており, 収縮低減剤 の使用量の増加に伴い長さ変化率が減少する結果となった。また, 収 縮低減剤種別による収縮低減効果を比較すると，使用量が $0.4 \%$ まで は S よりも H が高くなっているが，1.4\%以上では H と S の差はほと んどない。

図 2 にセメント重量に対する収縮低減剤使用量と質量変化率の関 係を示す。基本的に使用量の増加に伴い質量変化率は増加する傾向に あるが，H は使用量 $0.4 \%$ の場合にベースモルタルよりも質量変化率 が減少したため，使用量の多い $2.3 \%$ の場合でもベースモルタルと同 程度であった。液滴の曲率半径と蒸気分圧の平衡関係を表す Kelvin 式 (式(4)）より，同一相対圧で平衡する液滴の曲率半径は表面張力 が低いほど減少することから, 表面張力が低い収縮低減剤を用いた場 合には, より小さな細孔中の水分が逸散することになり質量変化率が 増加しやすくなると考えられる。

$$
\ln \left(\frac{P}{P_{0}}\right)=-\frac{2 \gamma V_{m}}{r R T}
$$

ここで， $P / P_{0}$ は相対圧， $\gamma$ は表面張力 $(\mathrm{N} / \mathrm{m}), V_{m}$ は水分子のモル体積 $\left(1.8 \times 10^{-5} \mathrm{~m}^{3} / \mathrm{mol}\right), r$ は毛細管半径 $(\mathrm{m}), R$ は気体定数 $(8.314 \mathrm{~J} / \mathrm{mol} \cdot \mathrm{K})$, $T$ は絶対温度 $(\mathrm{K})$ である。

\section{（2）凍結融解試験結果}

図 3 (a)，(b) に凍結融解試験結果を収縮低減剂種別ごとにそれぞ れ示す。図 3 （a）より，H の場合には使用量によらず耐凍害性が大 幅に低下していることがわかる。また図 3 （b）より，S の場合には， $\mathrm{H}$ に比べて耐凍害性は改善されているが, 使用量の増加に伴い相対動 弹性係数の低下が早期に生じ，S2.3 では $\mathrm{H}$ と同程度まで耐凍害性が 低下している。ただし，コンクリート試験体の寸法やサイクル条件等 により凍結融解試験結果が異なること ${ }^{26)}$, 水中凍結水中融解試験に おいて同一寸法の試験体であってもモルタル試験体の結果はコンク

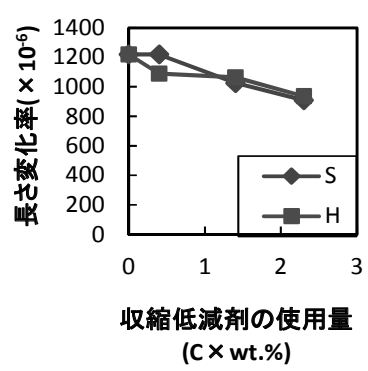

図 1 セメント重量に対する収 縮低減剤使用量と 長さ変化率の関係

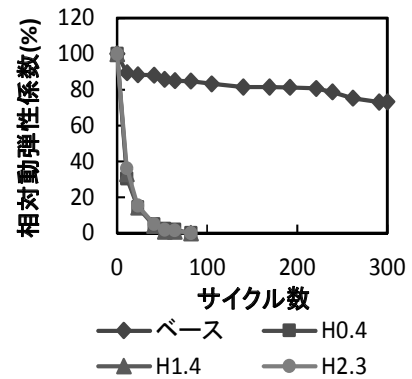

(a) Hの場合

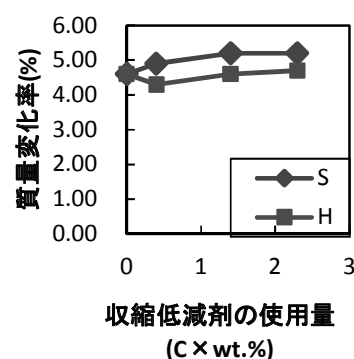

図 2 セメント重量に対する 収縮低減剤使用量と 質量変化率の関係

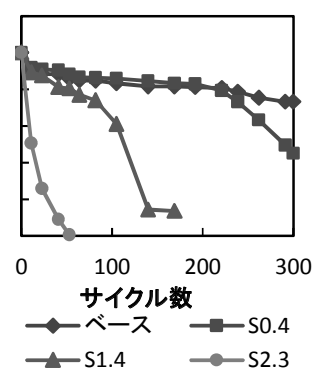

(b) S の場合

図 3 収縮低減剂種別ごとの凍結融解試験結果

リート試験体の結果よりも低下寸ること ${ }^{27}$ が指摘されているため, コンクリート試験体で同様の試験を行った場合, モルタル試験体と は異なる傾向になる可能性がある。

\section{（3）水銀圧入法による細孔構造測定結果}

図 4（a），(b)に収縮低減剤使用量による累積細孔容積の変化を 收縮低減剤種別ごとにそれぞれ示す。図 4(a)より，H では直径 $100 \mathrm{~nm}$ 以下の細孔量はベースモルタルよりも減少しているが, 収縮 低減剤の使用量による差はほとんどない。図 4(b)より，Sでは収縮 低減剤の使用の有無および使用量による差は認められない。

図 5 (a)，（b)に収縮低減剤使用量による細孔径分布の変化を収縮 低減剤種別ごとにそれぞれ示す。図 5 (a) より，H では使用量に よらず, 直径 $1000 \mathrm{~nm}$ 以下の細孔量がベースモルタルよりも減少し ていることがわかる。図 5 （b）より，S では直径 $20 \mathrm{~nm}$ 以下の細孔 量はベースモルタルに比べてすべて減少しているが，直径 20-30nm 付近の細孔量は使用量が多いほど増加している。また，直径 $30 \mathrm{~nm}$ 以上の細孔量はべースモルタルとほとんど差がない結果となった。

次に, 図 6 (a), (b)にインクボトル細孔の入口直径に対する累積 細孔容積を収縮低減剂種別ごとにそれぞれ示す。インクボトル細孔 とは気泡, 毛細管空隙, ゲル空隙とこれらよりもはるかに大きい空

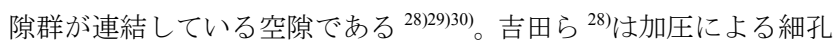
の損傷も把握可能な方法として, 水銀の圧入過程を数段階に設定し て各圧入過程の最低圧力における水銀量の差をインクボトル細孔 として算出する方法を提案しているが, 本実験では新ら ${ }^{13)}$ と同様に 2 回の水銀の圧入排出を繰り返すことで残存する水銀量をボトルネ ック部の直径, つまり入口直径に対するインクボトル細孔量として 検討した。図 6(a)より H ではベースモルタルよりもインクボトル 細孔量は減少しているが, 図 6(b)より S ではベースモルタルに比 ベてインクボトル細孔量は増加している。 


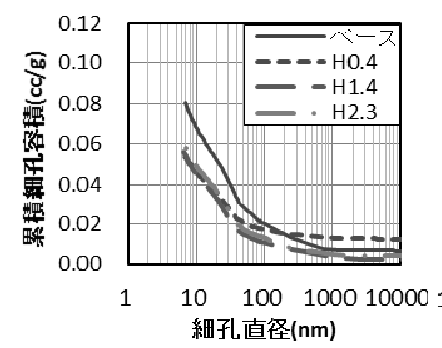

(a) Hの場合

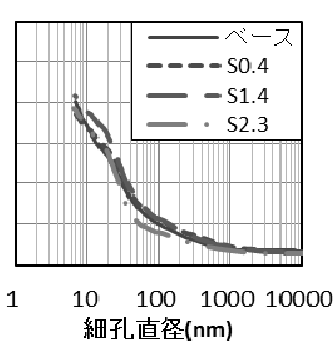

(b) S の場合

図 4 収縮低減剤使用量による累積細孔容積の結果

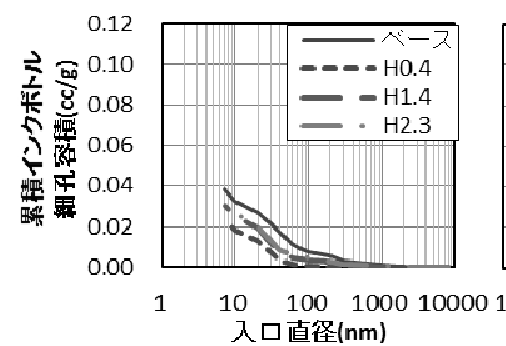

(a) Hの場合

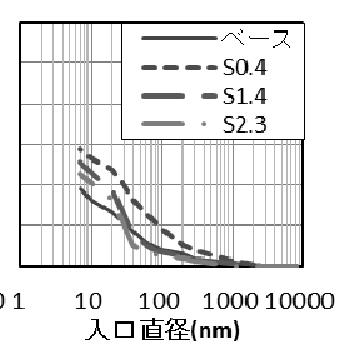

(b) S の場合

図 6 収縮低減剤使用量による累積インクボトル細孔容積の結果

図 7 (a) , (b)にインクボトル細孔の入口直径に対する細孔量の分 布を収縮低減剂種別ごとにそれぞれ示す。図 7 (a) より，H では心゙ ースモルタルと比べて入口直径 $20 \mathrm{~nm}$ 以下のインクボトル細孔量は同 程度となり, 入口直径 20-40nm のインクボトル細孔量は増加してい る。一方, 図 7 (b) より, S ではベースモルタルと比べて入口直径 $20 \mathrm{~nm}$ 以下のインクボトル細孔量にほとんど差が見られないが，入口 直径 20-50nm 付近のインクボトル細孔量は使用量が多いほど増加し, 図 5 に示寸細孔径分布の結果と類似している。また, 入口直径 $40-50 \mathrm{~nm}$ 以上の範囲におけるインクボトル細孔の分布は S0.4 を除き収縮低減 剂の種類によらず図 5 に示す細孔径分布の結果と同様の傾向となっ た。

\section{3-1-2 空隙構造と収縮性状の関係}

\section{（1）細孔構造と収縮性状の関係}

一般に, 55 から $60 \% \mathrm{RH}$ の湿度の場合にはセメント系材料の乾燥収 縮に影響を及ぼす細孔径は直径 $30 \mathrm{~nm}$ 以下といわれている ${ }^{31)}$ 。本研究 の乾燥收縮試験の条件である $20^{\circ} \mathrm{C} 60 \% \mathrm{RH}$ では, 式(4)の Kelvin 式に 対応する細孔径は直径 $4.2 \mathrm{~nm}$ 以上の範囲となる。しかし, 本研究での 水銀圧入法での測定可能な細孔径は直径 $6 \mathrm{~nm}$ 以上であることから, まず直径 6-30nm の細孔量が収縮性状に及ぼす影響を検討する。図 8 に直径 6-30nm の細孔量と長さ変化率の関係を示す。図 8 より, いず れの収縮低減剤を使用しても, ベースモルタルに比して直径 $6-30 \mathrm{~nm}$ の細孔量が減少し, 収縮が低減する傾向が見られる。しかし, 収縮低 減剤の使用量を考慮すると直径 6-30nm の細孔量と長さ変化率の間に 相関関係は認められなかった。

Kjellsen ら ${ }^{32}$ は, インクボトル細孔のような性質を持つ小さい空隙 と大きい空隙が連結している hollow-shell pore に存在する水分は，よ り小さい径の空隙内の水分が除去されるまで乾燥しないとしている。 そこで, 本実験で得られたインクボトル細孔の総量と長さ変化率の関 係を図 9 に示す。どちらの収縮低減剂においても両者に明確な相関は

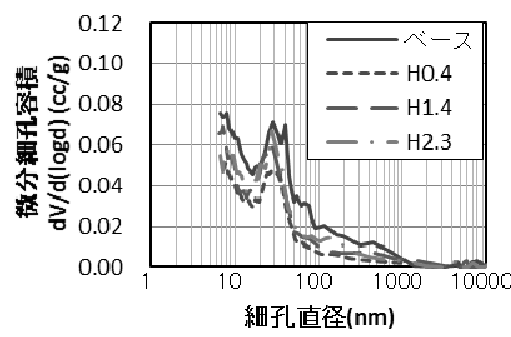

（a）Hの場合

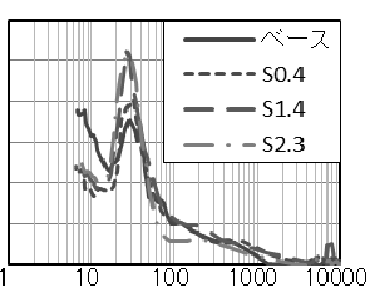

細孔直径 $(n m)$

（b）Sの場合

図 5 収縮低減剂使用量による細孔径分布の変化

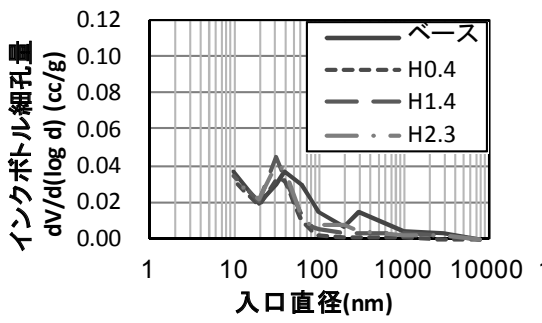

入口直径 $(\mathrm{nm})$

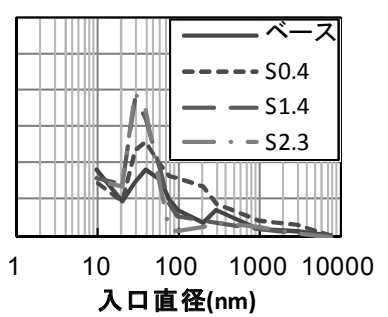

(b) $S$ 場合

図 7 収縮低減剤使用量による入口直径に対する インクボトル細孔の変化

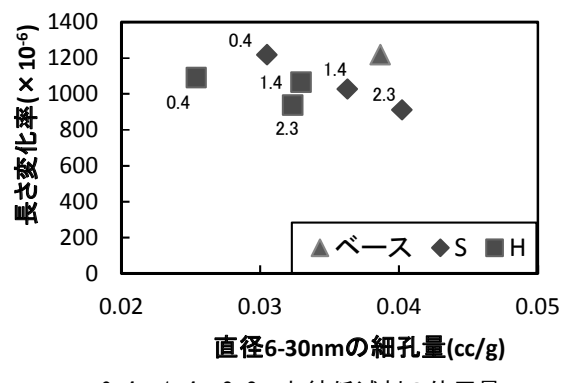

$* 0.4,1.4,2.3:$ 収縮低減剤の使用量

図 8 直径 6-30nm の細孔量と長さ変化率の関係

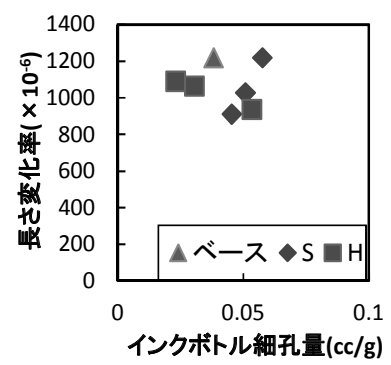

図 9 インクボトル細孔の総量と 長さ変化率の関係

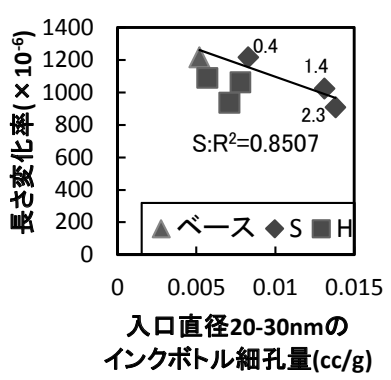

$* 0.4,1.4,2.3$

収縮低減剂の使用量

図 10 入口直径 $20-30 \mathrm{~nm}$ の

インクボトル細孔量と

長さ変化率の関係

表 3 区間細孔径の細孔量と長さ変化率の決定係数の関係

\begin{tabular}{|c|c|c|c|c|c|}
\hline \multirow{2}{*}{ 記号 } & 下限值 & \multicolumn{4}{|c|}{ 上限值 } \\
\cline { 2 - 6 } & $6 \mathrm{~nm}$ & $10 \mathrm{~nm}$ & $20 \mathrm{~nm}$ & $30 \mathrm{~nm}$ \\
\hline \multirow{4}{*}{$\mathrm{H}$} & $0 \mathrm{~nm}$ & 0.7740 & 0.8511 & 0.9701 & 0.9723 \\
\cline { 2 - 6 } & $6 \mathrm{~nm}$ & & 0.1614 & 0.2309 & 0.1763 \\
\cline { 2 - 6 } & $10 \mathrm{~nm}$ & & & 0.2499 & 0.1691 \\
\cline { 2 - 6 } & $20 \mathrm{~nm}$ & & & & 0.0434 \\
\hline \multirow{4}{*}{$\mathrm{S}$} & $0 \mathrm{~nm}$ & 0.1162 & 0.0307 & 0.0607 & 0.6519 \\
\cline { 2 - 6 } & $6 \mathrm{~nm}$ & & 0.063 & 0.0062 & 0.3476 \\
\cline { 2 - 6 } & $10 \mathrm{~nm}$ & & & 0.0077 & 0.7903 \\
\cline { 2 - 6 } & $20 \mathrm{~nm}$ & & & & 0.9584 \\
\hline
\end{tabular}


認められない。図 5(b)より, $\mathrm{S}$ において特徴的な分布を示した入口直 径 20-30nm のインクボトル細孔量と長さ変化率の関係を図 10 に示寸。 図 10 に示すように, この範囲のインクボトル細孔量が増加するほど 収縮は減少する傾向を示している。

次に, 長さ変化率と相関の高い細孔径の範囲を特定するために, 様々な細孔径の範囲と長さ変化率の相関係数を比較した。なお, 水銀 圧入法で測定できない直径 $6 \mathrm{~nm}$ 以下の細孔量については，アルキメ デス法による全空隙量から水銀圧入法により測定可能な直径 $6 \mathrm{~nm}$ 以 上の全細孔量を差し引くことによって算出した ${ }^{12)}$ 。表 3 に設定した 区間細孔径における細孔量と長さ変化率の決定係数を示す。 $\mathrm{H}$ の場合 には直径 $30 \mathrm{~nm}$ 以下の細孔量と長さ変化率の相関係数が 0.9723 と最も 高くなり, Bentur の結果 ${ }^{31)}$ で示された細孔範囲とほぼ対応した結果と なった。また, S の場合には直径 20-30nm の細孔量と長さ変化率の相 関が最も高くなった。これらの結果は，図 5(a)，(b)に示した細孔量 の変化が見られる細孔径の範囲と収縮低減剤によらず対応している ことから, 高い相関を示した範囲の細孔が乾燥収縮に及ぼす影響が高 いと考えられる。

\section{（2）比表面積と収縮性状の関係}

一般に, 乾燥収縮については上述のように細孔構造と関連付けて検 討されている。一方で，近年，丸山ら ${ }^{3)}$ は収縮駆動力に影響する分離 圧の観点から比表面積と乾燥収縮について検討を行い, さらにアルコ ール系収縮低減剤を使用した場合の収縮低減機構を水分の吸着の違 いによる比表面積の変化から説明している ${ }^{4)}$ 。そこで，本研究では 2 種類の収縮低減剤を用いて, 乾燥収縮と比表面積の関係を検討した。 図 11 に ESW 比表面積と長さ変化率の関係を示す。収縮低減剤を使 用した場合には比表面積と長さ変化率が共に減少している。さらに, $\mathrm{S}$ では使用量が増加するほど比表面積が減少し, 長さ変化率と比表面 積の間に高い相関が認められる。丸山ら ${ }^{4}$ は，水和生成物表面に収縮 低減剤の疎水基が存在することにより水分子の吸着が阻害されて水 蒸気吸着による比表面積が減少すること,また収縮低減剤の使用量が 多いほど水和生成物表面と水の間の相互作用力が弱まり分離圧が減 少し，収縮駆動力が低減していると指摘している。本実験の結果は収 縮低減剤の種類によらず，上述の丸山ら ${ }^{4)}$ の理論と合致している。

\section{3-1-3 空隙構造と耐凍害性の関係}

\section{（1）気泡組織と耐凍害性の関係}

図 12 に空気量と耐久性指数の関係, 図 13 に気泡間隔係数と耐久 性指数の関係をそれぞれ示寸。 H ではそれ自体がもつ消泡作用により ベースモルタルに比べて空気量と耐凍害性が減少し, 気泡間隔係数は 増加している。 S ではベースよりも空気量が増加しているが，使用量 が増加するほど空気量は減少し, 耐凍害性も低下している。しかし, 気泡間隔係数は使用量によらず耐凍害性に有効とされている $250 \mu \mathrm{m}$ 程度 ${ }^{33)}$ になっている。これらの結果は, S の混和によりべースモルタ ルよりも大きい気泡が増加することや, $\mathrm{S}$ の使用量の増加とともによ り小さい気泡が増加する傾向があることを示唆している。コンクリー トの耐凍害性を向上させるためには空気量の確保が重要であり， S は $\mathrm{H}$ よりも空気連行性および耐凍害性は改善されている。しかし，十分 な耐凍害性が確保されているとは言えず, S の耐凍害性低下について は気泡組織の変化のみでは説明ができない。また，西ら ${ }^{11}$ は鉱物油系 収縮低減剤を混和し，空気量を約 5\%確保したコンクリート試験体で は $70 \%$ 以上の耐久性指数が得られたという結果を報告していること

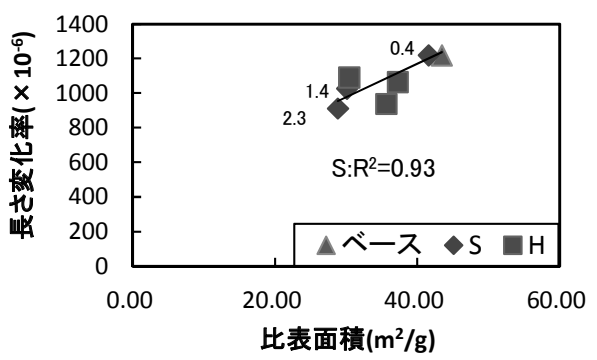

$* 0.4,1.4,2.3:$ 収縮低減剂の使用量

図 11 ESW 比表面積と長さ変化率の関係

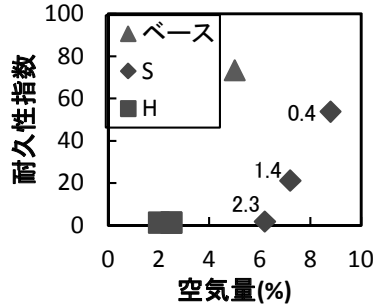

$* 0.4,1.4,2.3$

収縮低減剂の使用量

図 12 空気量と耐久性指数の 関係

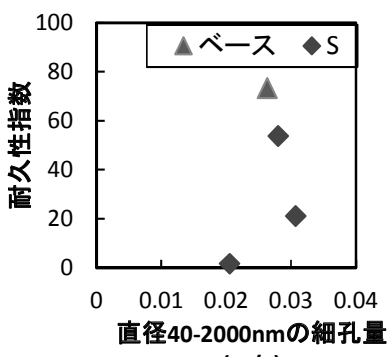

(cc/g)

図 14 直径 40-2000nm の 細孔量と耐久性指数の関係

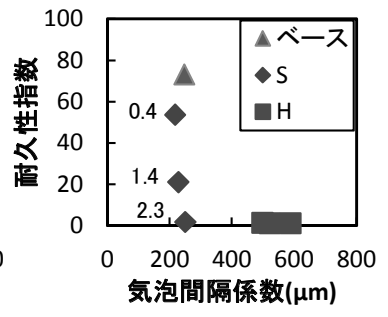

$* 0.4,1.4,2.3$

収縮低減剂の使用量

図 13 気泡間隔係数と 而久性指数の関係

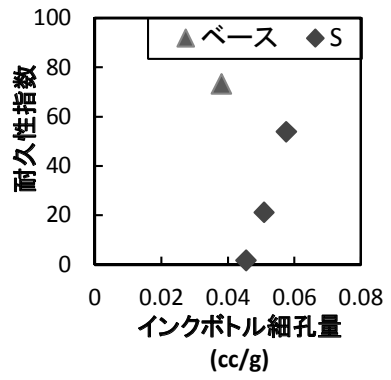

図 15 インクボトル細孔の

総量と耐久性指数の関係
から, コンクリート試験体とモルタル試験体との凍結融解試験結果 の関係性を今後, 検討する必要がある。H の耐凍害性低下の主要因 は消泡作用によるものと特定できることから, これ以降は $\mathrm{S}$ を対象 として耐凍害性低下の要因について検討を行う。

\section{（2）細孔構造と耐凍害性の関係}

細孔構造と耐凍害性の関係については多くの研究が行われてお り，その中で鎌田ら ${ }^{34)}$ は直径 40-2000nm の細孔量が多いほど而凍 害性が低下することを指摘している。また，青野ら ${ }^{35}$ は乾燥により C-S-H のシリケートアニオン鎖の縮重合が進行することで空隙構 造が粗大化し, 直径 40-2000nm の細孔量が増加して耐凍害性が低下 するとしている。さらに, 新ら ${ }^{13)}$ はインクボトル細孔量が増加する ほど耐凍害性が低下することを報告している。図 14 に S 使用し た場合の直径 40-2000nm の細孔量と耐久性指数の関係を示す。直径 40-2000nm の細孔量はベースモルタルに比べてほとんど差がない にもかかわらず耐凍害性は低下しており, 既往研究 ${ }^{32) 333 て ゙ い わ れ て ~}$ いるような直径 40-2000nm の細孔量が増加するほど耐凍害性が低 下するといら関係は認められない。さらに, インクボトル細孔の総 量と耐久性指数の関係を図 15 に示す。これについても既往研究 ${ }^{13)}$ 
で指摘されているようなインクボトル細孔の総量が増加するほど而 凍害性が低下寸るという関係は認められない。

そこで, $\mathrm{S}$ の使用により顕著な変化が見られた直径 20-30nm の細孔 量および入口直径 20-30nm のインクボトル細孔量と耐久性指数の関 係を図 16 および図 17 に示す。図 16 より，S では使用量が増加する ほど直径 20-30nm の細孔量が増加して耐凍害性が低下し, 図 17 より, 使用量が増加するにつれて入口直径 20-30nm のインクボトル細孔量 が増加し，これに伴い耐凍害性が低下していることがわかる。

\section{3-2 収縮低減剂を使用した混和剤溶液・細孔溶液の表面張力, 粘 性の影響}

\section{3-2-1 凍結水量に及ぼす影響に関する理論的検討}

凍害劣化に対して, 細孔中の水分の凍結温度が重要な役割を担って おり, 細孔径に依存した凍結点降下の理論式としての樋口式 ${ }^{8)}($ 式(5)) が良く知られている。

$$
\ln \left(\frac{T_{r}}{T_{s}}\right)=-\frac{2 \gamma V}{Q r}
$$

ここで, $T_{r}$ は細孔内の水分の凍結温度 $(\mathrm{K}), T_{s}$ : バルク水の凍結温度 $(273 \mathrm{~K}), \quad \gamma$ は液体の表面張力 $(\mathrm{mN} / \mathrm{m}), \quad V$ は液体のモル体積 $\left(18.02 \mathrm{~cm}^{3} / \mathrm{mol}\right), Q$ は分子融解熱 $\left(6.025 \times 10^{6} \mathrm{~mJ} / \mathrm{mol}\right), r$ は細孔半径 (m) である。

この式は細孔半径が小さいほど細孔中の水分の凍結温度が低下寸 ることを意味しており,コンクリートの凍害機構における細孔構造の 重要性を説明するためによく用いられてきたものである。しかし，こ の式は同時に細孔中の水分の表面張力も凍結温度に影響を及ぼすこ とを示しており, 表面張力が低いという特性を有する収縮低減剤の場 合には重要な意味を持つ。

ここで液体のモル体積および分子融解熱を一定, 固体表面に存在す る収縮低減剂によりポテンシャルの変化および不凍水膜の厚さに影 響はないと仮定し, 細孔溶液の表面張力と式(5)により算出された凍 結点降下の関係を細孔半径ごとに図 18 に示寸。図 18 より, 表面張力 が低いほじ凍結点降下が小さく, また細孔半径が大きいほど表面張力 の差が凍結点降下に及ぼす影響は小さくなることがわかる。また, 凍 結融解試験の最低温度である $-18^{\circ} \mathrm{C}$ においては, 式(5)から凍結する最 小の細孔直径は, 収縮低減剂を使用していない場合に約 $13 \mathrm{~nm}$ である のに対し，収縮低減剂を使用した場合には約 $5.5 \mathrm{~nm}$ となり，より小さ い細孔まで凍結するため凍結水量が増加する可能性が高い。

また, 既往研究において, 桂ら ${ }^{25)}$, 鎌田ら ${ }^{36)}$, 西ら ${ }^{6)} と ゙$ 多くの研 究者が凍結水量および凍結水率の変化に及ぼす要因と耐凍害性の関 係について検討し, 凍結水率が多いほど凍害劣化が進行することを指 摘していることから，式(5)を用いて凍結水率の理論值を算出するこ ととする。

まず，図 19 に混和剂溶液濃度と表面張力の関係を示す。純水の表 面張力は $72 \mathrm{mN} / \mathrm{m}$ であるのに対して, $\mathrm{AE}$ 減水剂および収縮低減剂の 溶液の表面張力は 30 から $40 \mathrm{mN} / \mathrm{m}$ と純水よりも大きく低下している。 また, 収縮低減剤溶液の表面張力は $\mathrm{AE}$ 減水剂溶液よりも低く, 各混 和剤の標準使用量の濃度範囲ではミセル限界濃度に達しており, 混和 剂濃度の増加による表面張力の変化はみられない。

そこで, 収縮低減剤を使用していないベースモルタルおよび収縮低 減剤 S を標準量使用した S1.4 を対象として, 凍結水率の算出に必要

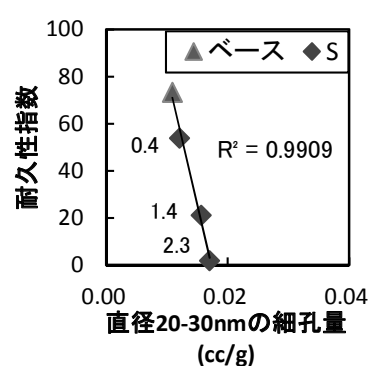

$* 0.4,1.4,2.3$ 収縮低減剂の使用量

図 16 直径 20-30nm の 細孔量と耐久性指数の関係

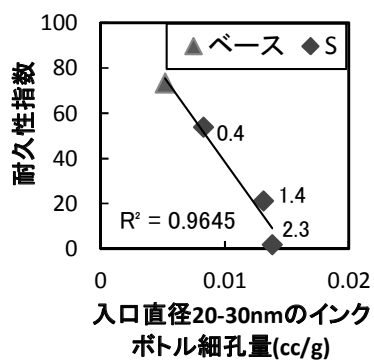

$* 0.4,1.4,2.3$

収縮低減剂の使用量

図 17 入口直径 $20-30 \mathrm{~nm}$ の インクボトル細孔量と 耐久性指数の関係

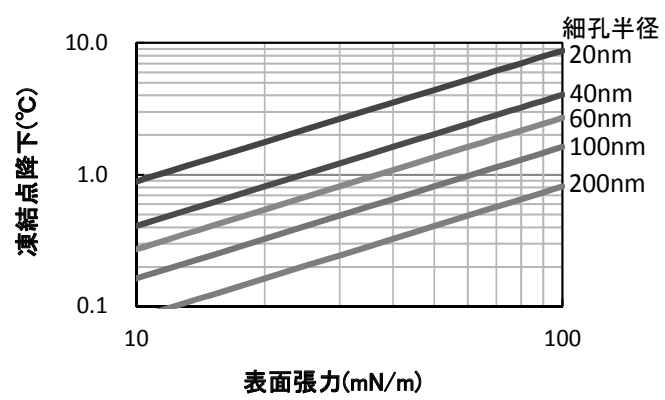

図 18 細孔溶液の表面張力と細孔径ごとの凍結点降下の関係

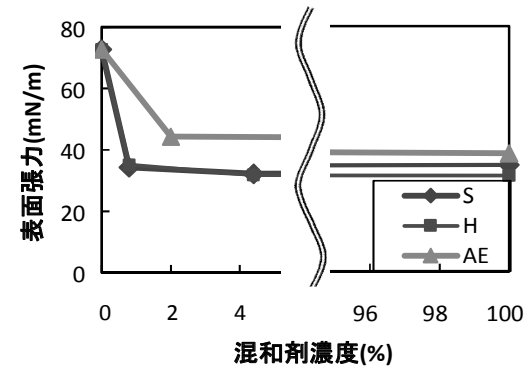

図 19 混和剂溶液の濃度と表面張力の関係

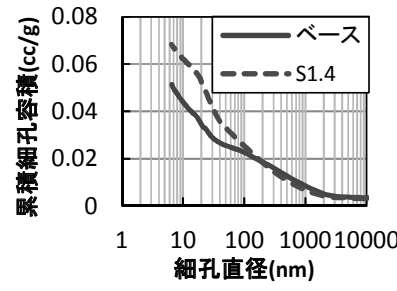

図 20 ベースモルタル．

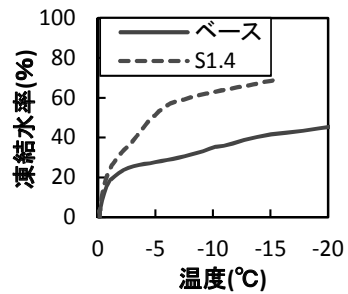

図 21 算出した凍結水率の 温度による変化
S1.4の累積細孔容積の測定結果

となる水銀圧入法による累積細孔容積の測定結果を図 20 に示す。 S1.4の累積細孔容積はベースモルタルに比べて約 33\%増加してい

る。なお凍結水率は, 全細孔が飽水状態であると仮定して, アルキ メデス法による全空隙量に対する細孔直径ごとの空隙率を求め, 図 19 に示した表面張力の実測值を用いて算出した。

図 21 に式(5)から理論的に算出した凍結水率の温度による変化を 示す。ベースモルタルに比べて S1.4 の凍結水率が 2 倍程度多くな っており, 収縮低減剤の使用による細孔構造の変化と収縮低減剤の 
表面張力の影響により凍結水率が増加することを示しており, 収縮低 減剤による耐凍害性低下の一因であることを示唆している。

\section{$3-2-2$ 凍結水量の実験的検証}

ここでは, 上記の収縮低減剤による凍結水率の変化を実験的に検証 するために, 交流二電極法によるモルタルの凍結水率の測定について 検討する。図 22 に交流二電極法による比抵抗の測定結果から求めた 温度とモルタルの凍結水率の関係を示す。凍結時にはいずれの試験体 でも $-5^{\circ} \mathrm{C}$ 程度で過冷却現象が生じ, 凍結水率が 30 40\%まで急増し ている。しかし, その後の凍結水率の変化はベースモルタルと S1.4 では類似しており, 凍結水率の最大值も同程度になっており, 図 21 に示したような収縮低減剤の使用による凍結水率の増加は認められ なかった。ここで, 収縮低減剤を使用したモルタルについては, 液体 のモル体積 $V$ および分子融解熱 $Q$ を水の場合と同值であるとの仮定 を式(5)に適用して凍結温度および凍結水率を検討してきたが，上述 の結果から収縮低減剂を使用する場合には $V$ および $Q$ は水とは異な る值となる可能性が考えられ, これらについては今後検討が必要であ る。また, 凍結過程において過冷却後に温度が $0{ }^{\circ} \mathrm{C} に$ 戻っていないこ と, 融解過程において収縮低減剤を使用した $\mathrm{S} 1.4$ の $0^{\circ} \mathrm{C}$ 付近での融解 挙動がベースモルタルより緩やかで $0{ }^{\circ} \mathrm{C} に$ 達しても凍結水率が $0 \%$ に 戻らない結果を示している。この理由については, 測定時のデータ収 録のインターバルの影響, 凍結による細孔溶液のイオン濃度の変化の 影響が考えられるが，現段階では明らかではない。

図 23 にセメントペーストから搾り出し法により採取した細孔溶液 の表面張力の実測結果を示す。なお,ここでの混和剤濃度はセメント ペースト混練時の練混ぜ水の混和剤濃度である。混和剤を使用せずに 混練したセメントペーストの細孔溶液の表面張力も, 混和剤を含む細 孔溶液の表面張力と同程度であり, 細孔溶液の表面張力は混和剂種別 および濃度によらず $40 \mathrm{mN} / \mathrm{m}$ 程度とほぼ一定になっている。これは佐 久田ら ${ }^{9)}$ と同様の結果であり, 硬化セメントペースト中の細孔溶液に は様々なイオンが含まれているため, 混和剤を使用しない場合にも細 孔溶液の表面張力が低下していることを示している。このことが，図 22 で示したようにモルタルの凍結水率の実測結果に収縮低減剂の使 用の有無による差が見られなかった原因と考えられる。

さらに, セメントペーストから採取した細孔溶液の表面張力による 凍結温度の変化を明確にするため, 均一で小さい細孔径を有する多孔 質シリカを用い，過冷却の影響を考慮して融点を測定した。図 24 に セメントペーストから採取した細孔溶液を含浸させた多孔質シリカ の低温 DSC による凍結温度の測定結果を理論值と共に示寸。多孔質 シリカは半径 $5 \mathrm{~nm}$ の均一孔を有するもので, 式(5)から表面張力に対 する凍結温度（融点）の理論值を算出することができる。半径 $5 \mathrm{~nm}$ の細孔中に存在する水分の融点の理論值は, 表面張力 $72 \mathrm{mN} / \mathrm{m}$ の純水 では約 $-23^{\circ} \mathrm{C}$, 表面張力 $38 \mathrm{mN} / \mathrm{m}$ を示す濃度 $4.4 \%$ の収縮低減剤 $\mathrm{S}$ 溶液 の場合には約 $-10^{\circ} \mathrm{C}$ であり, 表面張力の低い収縮低減剂を使用した場 合には融点が上昇することになる。しかし，細孔溶液を含浸させたシ リカゲルの融点の実測結果は, 収縮低減剂の使用の有無による差はほ とんど認められず, 図 23 に示した細孔溶液の表面張力の実測值から 算出した凍結温度とほぼ対応する結果となった。一方, Sant $ら^{377}$ は, 径 $4 \mathrm{~nm}$ および $200 \mathrm{~nm}$ の細孔をもつバイコールガラスに含浸させた脱 イオン化水，収縮低減剂を使用していない細孔溶液，5\%および $10 \%$ 濃度の収縮低減剂を使用した細孔溶液の 4 種類を用いて融点の測定

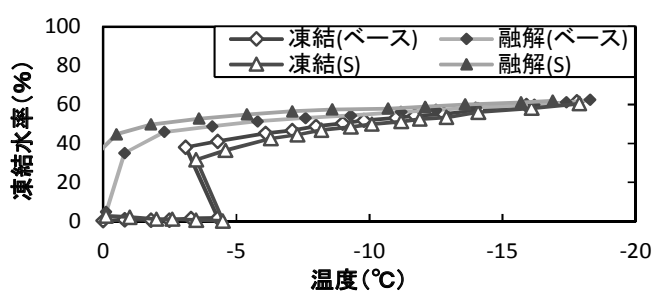

図 22 交流二電極法による比抵抗の測定結果から求めた 温度とモルタルの凍結水率の関係

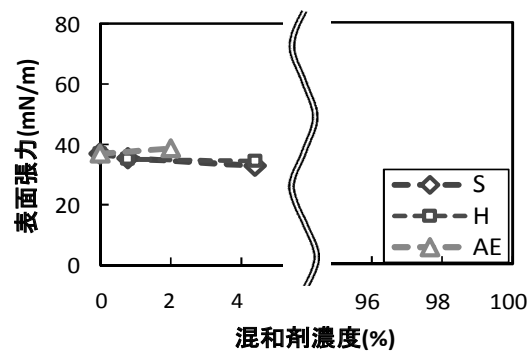

図 23 セメントペーストから搾り出し法により抽出した 細孔溶液の表面張力の実測結果

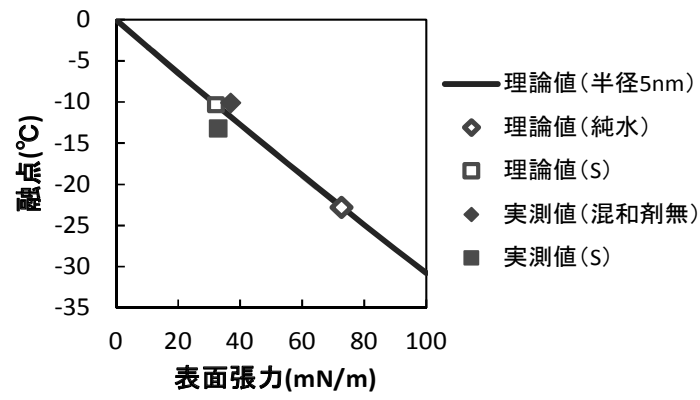

図24 セメントペーストから抽出した細孔溶液を 含浸させた多孔質シリカの凍結温度の測定結果と理論值

を行った結果，収縮低減剂を使用した細孔溶液の融点が低下するこ とを報告している。これは, 濃度が高いほど融点は高くなるという 本実験の結果とは異なる。Sant $5^{37)}$ の用いた収縮低減剤の濃度は一 般に使用される範囲を超過しており，濃度が高い場合には，溶質の 濃度によるモル凝固点降下の影響が顕著に現れるが, 本実験のよう に一般使用量の濃度範囲においては, 表面張力低下による凍結温度 上昇の影響が大きいと推察される。しかし, 練混ぜ水として収縮低 減剤を使用した場合には表面張力が低下寸ることが確認されたが， モルタル中の細孔溶液としては, 収縮低減剂の使用の有無, 混和剤 の種類, 使用量による表面張力の差異はなく, 細孔溶液の凍結温度, 凍結水率の変化には影響していないといえる。つまり, 収縮低減剂 による耐凍害性低下の原因として表面張力とは異なる要因を考え なければならない。また, 同様の理由で, 収縮低減剤の収縮低減機 構の主要因は表面張力以外であることも明らかとなった。さらに, 収縮低減剂の使用量を一般的な範囲とする場合には濃度の変化に よるモル凝固点降下の影響はほとんどないと考えられるが, 温度の 低下に伴う収縮低減剂の濃縮が凍結温度に及ぼす影響について検 討する必要がある。

\section{$3-2-3$ 混和剤溶液の粘性と耐凍害性の関係}

凍害劣化機構として T.C.Powers の水圧説 ${ }^{38)}$ が一般に支持されて おり, 凍結時に生じる不凍水の移動に伴い不凍水圧が生じ, その不 
凍水圧は毛細管空隙水の粘性係数に依存することが知られている。ま た，桂ら ${ }^{39}$ は，Poiseuille の式から直管内に存在する非圧縮性液体の 流速 $G$ を式(6)により示し, 液体が凍結する細孔内の不凍水圧を $P_{l}$, 圧力緩和の役割をする気泡と毛細管空隙の連結部での圧力 $P_{2}=0$ とし た場合の不凍水の流速 $G$ と凍結点での圧力 $P_{I}$ の関係を式(7)で示して いる。

$$
\begin{aligned}
& G=\frac{\pi r^{4}}{8 \eta} \frac{d P}{d x} \\
& P_{1}=\frac{8 \eta G l}{n \pi r^{4}}
\end{aligned}
$$

ここで, $G$ は流速 $\left(\mathrm{m}^{3} / \mathrm{s}\right), r$ は液体が移動する管の半径 $(\mathrm{m}), d P / d x$ は 圧力勾配 $\left(\mathrm{N} / \mathrm{m}^{3}\right), \quad \eta$ は液体の粘性係数 $\left(\mathrm{Ns} / \mathrm{m}^{2}\right), \quad l$ は凍結点と気泡の距 離 $(\mathrm{m}), R$ は気泡へつながる毛細管空隙の半径 $(\mathrm{m}), N$ は気泡へつなが る半径 $r$ と長さ $l$ の毛細管空隙の本数(本)である。

これらの式から, 液体が移動する管の半径および圧力勾配が一定の 場合, 液体の粘性が大きいほど流速が小さくなることがわかる。また, $P_{I}$ がモルタルの引張強度を超えると組織が破壊されて凍害劣化が生 じるが, 不凍水圧は気泡とつながる毛細管空隙を移動する液体の粘度 $\eta$ の影響も受けることになる。ここで, 収縮低減剤は水よりも粘度が 高いとされているため, 凍結時に生じる不凍水圧が上昇し, 耐凍害性 に影響を及ぼす可能性がある。

ここでは, S1.4 のモルタルに相当する S の濃度 $2.73 \%$ の収縮低減剂 溶液と純水の粘度を常温範囲で測定した。図 25 に混和剂溶液の温度 と粘度の関係を示す。なお， $0^{\circ} \mathrm{C}$ 以下の温度での粘度の測定は行って いないが, 液体の温度の逆数と対数表示した粘度に直線関係があり, これが融点以下の温度にも適用できるという大野 ${ }^{40)}$ の研究結果を踏 まえて, 常温範囲での測定結果の回帰式を補外して表示している。純 水と収縮低減剤溶液の粘度は低温になるほど差が増加することがわ かる。

さらに, 凍結時には水晶周囲で収縮低減剤が濃縮することが考えら れ,この濃縮によりさらに粘度が増大寸る可能性もある。図 26 に $15^{\circ} \mathrm{C}$ における収縮低減剤溶液の濃度と粘度の関係を示しており, 濃度を変 えた収縮低減剤溶液の粘度の実測值とその直線回帰式を示している。 収縮低減剂溶液の濃度が増加するほど粘度は増加し, 両者は直線関係 にある。ここで, 収縮低減剤溶液の凍結による濃縮現象を確認するた めに, 収縮低減剤溶液を冷却, 凍結させ， $0^{\circ} \mathrm{C}$ 以下で凍結していない 液体を採取して $15^{\circ} \mathrm{C}$ での粘度を測定した。その結果, 収縮低減剤溶 液の粘度は $1.23 \mathrm{mPa} \cdot \mathrm{s}$ であったのに対し, 凍結時の採取した溶液の粘 度は $1.59 \mathrm{mPa} \cdot \mathrm{s}$ となった。この結果を図 26 の回帰線上にプロットす ると, 粘度が $1.59 \mathrm{mPa} \cdot \mathrm{s}$ に対応する収縮低減剤濃度は約 $12 \%$ となり, 凍結によって収縮低減剂溶液の濃度の濃縮と粘度の増大が生じるこ とが確認された。式(7)より，収縮低減剤の使用の有無によらず $G, l$ および $n$ を定数とすると, 細孔内の水分の粘度が大きいほど大きな細 孔でもモルタルの引張強度を超過して組織を破壊する可能性がある。 また, 引張強度を超える細孔径が大きいほど, 不凍水圧の増大に影響 を及ぼす細孔が増加するため, 耐凍害性低下の一因となる可能性があ る。現状では, 細孔溶液の粘度の変化による不凍水圧の具体的な算出 はできていないが, 理論的検討と実測データから収縮低減剤による耐 凍害性低下の原因として細孔溶液の粘性が影響している可能性を示 唆した。

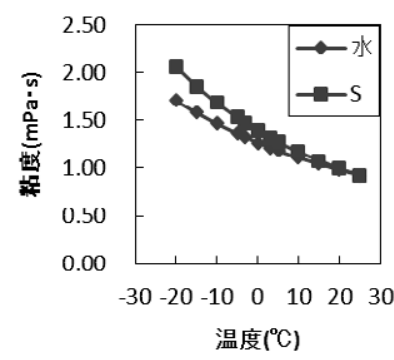

図 25 混和剂溶液の温度と 粘度の関係

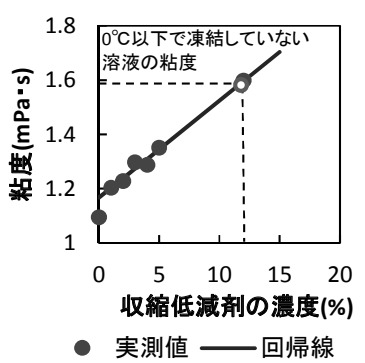

図 $26 \quad 15^{\circ} \mathrm{C}$ での収縮低減剤 溶液の濃度と粘度の関係

\section{4. 結論}

本研究ではアルコール系の従来型収縮低減剤 $(\mathrm{H})$ および鉱物油系 の改良型収縮低減剂(S)を使用したモルタルの収縮性状および而凍 害性に影響を及ぼす可能性のある要因として空隙構造による影響, 混和剤溶液および搾り出しにより抽出した細孔溶液の表面張力お よび粘性による影響について検討した。得られた結果を以下に示す。

(1) いずれの収縮低減剤を使用してもベースモルタルよりも収縮 量が減少し, 収縮低減剂 S の場合には使用量が増加するほど直 径 20-30nm の細孔量および入口直径 20-30nm のインクボトル 細孔量が増加し,さらに比表面積が小さくなり収縮が低減した。

（2）収縮低減剤使用の有無によらず, セメントペーストから搾り出 しにより採取した細孔溶液の表面張力は純水の約 $1 / 2$ の值であ り, 表面張力はモルタルの収縮低減にほとんど影響を及ぼして いない。

（3）収縮低減剤 $\mathrm{H}$ を使用するとそれ自体の消泡作用により空気量 が減少し, 気泡間隔係数が増加することにより耐凍害性が低下 した。一方, 収縮低減剤 S はベースモルタルよりも空気量は増 加し，気泡間隔係数も耐凍害性に有効とされる $250 \mu \mathrm{m}$ 程度と なっているが, 収縮低減剤の使用量が増加寸るほど而凍害性が 低下寸る傾向が確認された。

（4）収縮低減剤 S を混入したモルタルでは使用量が増加するほど 直径 20-30nm の細孔量および入口直径 20-30nm のインクボト ル細孔量が増加し，耐凍害性が低下寸る傾向が確認された。

（5）セメントペーストから採取した細孔溶液の融点およびモルタ ルの凍結水率に収縮低減剂使用の有無による差が見られず, 収 縮低減剤の表面張力低下が而凍害性に及ぼす影響は明確には 認められなかった。

（6）低温になるほど収縮低減剤を含む混和剂溶液の粘度は純水よ りも高くなり,さらに混和剤溶液の凍結が進行すると収縮低減 剂の濃縮に伴って粘度が増加するため, 凍結時に発生する不凍 水圧が上昇して耐凍害性を低下させる可能性があることを示 唆した。

\section{謝辞}

本研究の実施にあたり, 北方建築総合研究所・谷口円氏, 株式会 社フローリック・西祐宜氏, 光石尚道氏の協力を得た。記して, 謝 意を表す。 


\section{参考文献}

1) 西祐宜, 橋爪進, 名和豊春: 凍結融解抵抗性を改善した収縮低減剤の開発, コンクリート工学年次論文集, Vol.32, No.1, pp143-148, 2009

2）福島浩樹，石森正俊，胡桃澤清文，名和豊春：乾湿繰返しによるセメント 硬化体の収縮・膨張挙動, セメント・コンクリート論文集, No.64, pp.74-81, 2010

3) 丸山一平, 岸直哉: セメント硬化体の収縮理論, 日本建築学会構造系論文 集，Vol.74，No.642，pp. 1395-1403, 2009.8

4) 丸山一平, 岸直哉: 収縮低減剂の作用機構, 日本建築学会構造系論文集, Vol.74, No.645, pp.1895-1903, 2009.11

5) 高田良章，西祐宜，橋爪進，名和豊春 : 而凍害性を改善した収縮低減剂の 諸特性, 日本建築学会大会学術講演梗概集, A-1, pp.961-962, 2010

6) 西祐宜, 名和豊春: 収縮低減剤がモルタルの乾燥収縮および凍結融解挙動 に及ぼす影響，コンクリート工学年次論文集，Vol.29, No.1，2007

7）鳴海玲子，張文艶，岸本嘉彦，濱幸雄：収縮低減剤を用いたモルタルの収 縮性状と耐凍害性に及ぼす空隙構造の影響, コンクリート工学年次論文集, Vol.34, No.1, pp.148-153, 2012

8）樋口泉: 多孔体の毛細管に分散した物質の特性と毛管構造, 表面, Vol.6, No.3, 1968

9) 佐久田昌治, 斉藤俊夫, 大野定俊, 嵩英雄 : コンクリート乾燥収縮低減剂 の実用化に関する研究，その 2.収縮低減剤の作用機構に関する一考察，日本 建築学会大会学術講演梗概集, pp.489-490，1984.10

10) 張英華，藤原忠司，柴田卓也：硬化セメントペーストの自己収縮に及ぼ す混和剤の影響，コンクリート工学年次論文集，Vol.26，No.1，pp.459-464， 2004

11）張友海，藤原忠司，小山田哲也：コンクリートの耐凍害性に及ぼす収縮 低減剤の影響，セメント・コンクリート論文集，No.63，pp.458-464， 2009

12）青野義道，松下文明，柴田純夫，濱幸雄：乾燥および乾湿繰返しによる 硬化セメントペーストの微細構造変化, コンクリート工学年次論文集, Vol.29, No.1，pp.993-998, 2007

13）新大軌，濱幸雄，涉谷将，青野義道：環境変化養生によるモルタルの細 孔構造と耐凍害性の変化, セメント・コンクリート論文集, No.63, pp.155-160, 2009

14）岸本嘉彦, 高橋力也, 濱幸雄, 新大軌 : セメント硬化体の水蒸気吸脱着 等温線測定に及ぼす試料粒径の影響, コンクリート工学年次論文集, Vol.32, No.1, pp.581-586, 2010

15) 丸山一平，西岡由紀子，五十嵐豪：乾燥化におけるセメントペーストの 物性変化一I . 窒素および水蒸気吸着等温線から見た微細構造変化一, 第 67 回セメント技術大会講演要旨，pp.174-175，2013

16) 松下文明, 青野義道, 柴田純夫 : 水蒸気吸着等温線によるセメント系材 料の細孔構造解析, コンクリート工学年次論文集, Vol.26, No.1, pp.573-578, 2004

17）青野義道，松下文明，柴田純夫，濱幸雄：ガス吸着等温線による硬化セ メントペースト中の C-S-H の構造解析, コンクリート工学年次論文集, Vol.31 No.1, pp.739-744, 2009

18) J. Adolphs, M. J. Setzer : Description of Gas Adsorption Isotherms on Porous and Dispersed Systems with the Excess Surface Work Model, Journal of Colloid and Interface Science, Vol.207, Issue 2, pp.349-354, 1998.11

19) J. Adolphs : Excess surface work-A modeless way of getting surface energies and specific surface areas directly from sorption isotherm, Applied Surface Science, Vol.253, Issue 13, pp.5646-5649, 2007.4

20) S. Brunauer et al. : Adsorption of gases in multimolecular layers, Journal of the American Chemical Society, Vol.60, Issue 2, pp.309-319, 1938
21) American Standard, ASTM C 457-98. Standard Method for Microscopical Determination of Parameters of the Air-Void System in Hardened Concrete.

22) Adamson, A.W., Gast, A.P. : Physical Chemistry of Surfaces, sixth ed. John, Wiley \& Sons, Inc., New York, 1997

23) Kazuhiko Ishikiriyama, Minoru Todoki : Evaluation of water in silica pores using differential scanning calorimetry, Thermochemical Acta 256, pp.213-226, 1995

24) Kazuhiko Ishikiriyama, Minoru Todoki, Kinshi Moromura : Pore Size Distribution (PSD) Measurements of Silica Gels by Means of Differential Scanning Calorimetry, Journal of colloid and interface science 171, pp.92-102, 1995

25）桂修，吉野利幸，鎌田英治：交流 2 電極法によるセメント硬化体中の凍 結水量測定と水分凍結の細孔構造依存性, コンクリート工学論文集, 第 7 巻，第 1 号，pp.57-66，1996.1

26）洪悦郎，長谷川寿夫 : コンクリートの凍結融解試験方法の動向，コンク リート工学, Vol.19, No.9, pp.16-22, 1981.9

27) 中村暢, 濱幸雄 : モルタル・コンクリートの凍結融解試験結果に及ぼす 試験体寸法・形状の影響, 日本建築学会大会学術講演梗概集, A-1, pp.643-644, 2013.8

28）吉田亮，岸利治：水銀圧入過程における内部空気泡の関与と水銀圧入 の 有効圧力範囲に関する研究, セメント・コンクリート論文集, No.60, pp.68-75, 2006

29) Kalliopi K. Aligizaki : Pore structure of cement-based materials-Testing, Interpretation and Requirements, Mordern Concrete Technology 12

30) Rosa Maria Espinosa, Lutz Franke : Influence of the age and drying process on pore structure and sorption isotherm of hardened cement paste, Cement and Concrete Research 36, pp.1969-1984, 2006

31) A. Bentur : Effect of curing temperature on the pore structure of tricalcium silicate pastes, J. Colloid Interface Sci., 74(2), pp.549-560, 1980

32) Knut O. Kjellsen, Elisabeth Helsing Atlassi : Pore structure of cement silica fume systems Presence of hollow-shell pores, Cement and Concrete Research 29, pp.133-142, 1999

33) ACI Commite, 212 : Admixture for Concrete, Jour ACI, Vol.11, No.11, pp.1481-1524, 1963

34）鎌田英治：コンクリートの凍害と細孔構造，コンクリート工学年次論文 報告集，Vol.10，No.1，pp.51-60，1988

35）青野義道，松下文明，柴田純夫，濱幸雄 : 乾燥および乾湿繰返しによる 硬化セメントペーストの微細構造変化と耐凍害性への影響, コンクリート工 学年次論文集, Vol.30, No.1, pp.921-926, 2008

36) 鎌田英治, 大内一之，吉野利幸：硬化セメントペーストの凍害と細孔構 造の役割について，セメント技術年報，No.30，pp.292-295， 1976

37) Gaurav Sant, Dale Bentz, Jason Weiss : Capillary porosity depercolation in cement-based materials: Measurement techniques and factors which influence their interpretation, Cement and Concrete Research 41, pp.854-864, 2011

38) T. C. Powers : A Working Hypothesis for Further Studies of Frost Resistance of Concrete, Journal of American Concrete Institute, Vol.16, No.4, pp.245-272, 1945

39）桂修，吉野利幸，鎌田英治：セメント硬化体の凍害機構モデル，コンク リート工学論文集，Vol.11，No.2，pp.49-62，2000.5

40) 大野武敏 : 融点近くにおける液体の粘性係数, 低温科学物理篇, 北海道 大学学位論文, Vol.18，1959

（2013年11月10日原稿受理，2014年 3 月 5 日採用決定） 